\title{
The Year of the Dog
}

\author{
Myrella Roy
}

$I^{\prime}$

know! According to the Chinese zodiac, 2010 was the Year of

the Tiger. However, I will remember it as the year my mother had to move into a seniors' residence, and I adopted her then 12-year-old dog, Moka. The dog adapted to me and my hectic lifestyle much more readily than I did to him and his needs. That experience led me to read up on the reputed personality traits of the Sign of the Dog, discovering in the process that many of them can be related to the accomplishments of the Canadian Society of Hospital Pharmacists (CSHP) in 2010.

\section{Attentive}

CSHP listened to the needs of its members for distance continuing education and launched its new e-learning platform called "AdvancingIn Medication Management" in partnership with AdvancingIn and rxBriefCase Inc. In this era of budgetary constraints and cutbacks to continuing education budgets in hospitals, distance learning has become essential. AdvancingIn Medication Management delivers innovative educational programs to pharmacists and other health care professionals across the country. Four educational sessions recorded during the 2010 Professional Practice Conference have been converted to online education courses (www.cshp.ca/programs/onlineeducation/ index_e.asp). All programs are accredited by the Canadian Council on Continuing Education in Pharmacy (CCCEP).

\section{Exuberant}

CSHP was delighted at a flurry of media attention received last fall. Society representatives spoke to the National Post and to CBC Radio Saskatchewan about look-alike drug packaging and label design and the risk of adverse drug events. The value of automated identification (e.g., bar-coding) as a tool to reduce the risk of adverse drug events was highlighted, and the importance of accelerating the implementation of such technology in hospitals and related health care settings was emphasized. CSHP was also invited by The Canadian Press to comment on the impact of provincial drug information systems before release of a report from Canada Health Infoway. To find out how your Society speaks to the media on behalf of hospital pharmacists, visit the "CSHP in the News" web page at www.cshp.ca/ advocacy/cshpnews_e.asp.

\section{Idealistic}

CSHP is visionary in planning its future and that of hospital pharmacy practice. Two CSHP representatives participated in the Pharmacy Practice Model Initiative (PPMI) Summit jointly sponsored by the American Society of Health-System Pharmacists (ASHP) and the ASHP Foundation in late 2010 (www.ashp.org/PPMI). The goal of this initiative is

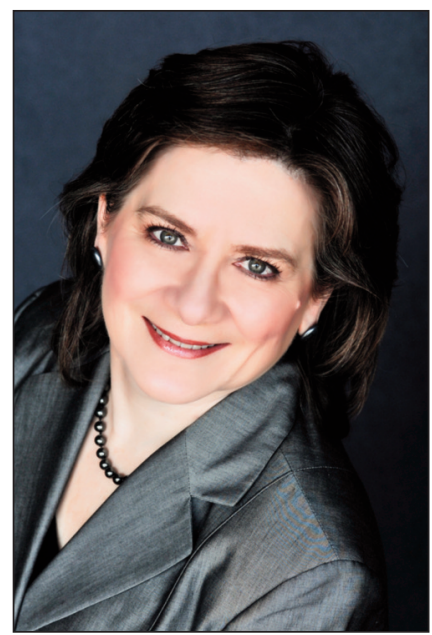
to significantly advance the health and well-being of patients in hospitals and health systems by developing and disseminating optimal pharmacy practice models that are based on the effective use of pharmacists as direct patient care providers. Over 100 invited voting participants reached consensus on more than 160 recommendations affirming the need to move pharmacists closer to patients, to take responsibility for safe use of medications, to ensure a well-developed technician workforce, to widely adopt technology, and to value other stakeholders. The Summit proceedings and briefing papers will be published in the American Journal of Health-System Pharmacy in spring 2011.

Last summer CSHP took the next step toward its strategic plan, Vision 2014, by holding a facilitated session with its Council, Branch presidents, and staff members. The findings of a CSHP member survey and an environmental scan were used in revising the Society's mission, vision, and values and in setting strategic directions to take up the following challenges: develop a highly focused and manageable program and service plan, acquire the needed revenues, rejuvenate the volunteer base, recruit and engage members, and decide on the extent of CSHP's voice and profile. CSHP Council will approve the 2011-2014 strategic plan at its midterm meeting in March 2011.

\section{Practical}

CSHP provided support on a number of concrete issues 
faced by hospital pharmacy practice. In a survey conducted by the Society in May 2009, the 74 directors and managers of hospital pharmacy who responded expressed strong concerns about the capacity of hospitals to expand experiential education for student pharmacists in the hospital setting by providing longer placements or accommodating larger cohorts. Since then, CSHP has been working closely with the Association of Deans of Pharmacy of Canada (ADPC) and Pharmacy Experiential Programs of Canada (PEP Canada) in seeking solutions to alleviate these concerns. A think tank involving deans of pharmacy, pharmacy preceptors, and directors and managers of hospital pharmacy in February 2010 and a follow-up meeting with ADPC and PEP Canada in June 2010 yielded a series of recommendations and an action plan that should help to resolve current and future issues of capacity and workload associated with student pharmacist experiential education in hospitals.

CSHP's Official Publications have long been valued references that guide and advance the practice of pharmacy in Canada (www.cshp.ca/productsServices/officialPublications/ type_e.asp). New and revised releases include Journal Clubs: Guidelines, Hospital Pharmacists: Information Paper on Direct Patient Care and Beyond, and Hospital Pharmacists: Information Paper on Enhancing Quality and Safety in Medication Use.

\section{Responsible}

CSHP conscientiously fulfilled its advocacy duty toward the membership. We conducted a campaign advocating the authority to prescribe by pharmacists within collaborative professional environments (www.cshp.ca/advocacy/campaigns/ prescribingPharm_e.asp). CSHP National also assisted its Ontario Branch with writing to the Ontario Minister of Health with regard to drug system reform (www.cshpontario.ca/ web/la//fi/f620c28e9a0b446894ca8b46ed6dc3e7/get_file.asp) and its Alberta Branch with writing to the Alberta Minister's Advisory Committee on Health to express the Branch's views about implementing the 4 recommendations in the report on the Alberta Health Act (www.cshp.ca/advocacy/CSHPspeaks/ ABrecommendations_e.asp).

CSHP also provided feedback to the Association of Faculties of Pharmacy of Canada (for the draft educational outcomes for first professional degree programs in pharmacy and for the draft levels of performance expected of graduates from these programs) and to Health Canada (for the temporary methadone exemptions process for physicians working in a hospital setting and for the local destruction of narcotics, controlled drugs, and restricted drugs). Last but not least, CSHP endorsed the adoption of the GS1 global standards for automated identification (e.g., bar-coding) of pharmaceutical products in Canada and the Joint Technical Statement on Pharmaceutical Automated Identification and Product Database Requirements issued by the Institute for Safe Medication Practices Canada and the Canadian Patient Safety Institute (www.ismp-canada.org/barcoding/ index.htm).

CSHP further demonstrated its trustworthiness by appointing representatives to external organizations, namely, the Steering Committee for the Continuing Professional Development Summit sponsored by CCCEP and the National Faculty for the Canadian Guideline for Safe and Effective Use of Opioids for Chronic Non-Cancer Pain (http://nationalpaincentre. mcmaster.ca/opioid/index.html.

\section{Sociable}

This past year, the CSHP staff exhibited their familiar kindness. We bade a final adieu to Barbara Wells, who was the CSHP 2015 Project Coordinator; we said farewell to Sonya Heggart-Long and Julie Maillet, who left their positions as Publications Administrator and Office Clerk, respectively; and we reassigned Colleen Drake to the permanent position of Publications Administrator. In turn, we welcomed Carolyn Bornstein as the new CSHP 2015 Project Coordinator, Amanda Cuirrier as our Office Clerk, Rosemary Pantalone as the Awards and Pharmacy Specialty Networks Administrator, and Moka as temporary CSHP Mascot.

Yes, you read correctly! Moka joined the staff for a few weeks while he required intensive ophthalmic treatment from me for a corneal ulcer. This experience taught me a few more dog tricks and bonded owner and pet irrevocably.

Myrella Roy, BScPhm, PharmD, FCCP, is Executive Director of the CSHP. 